\begin{tabular}{|c|c|c|}
\hline Beitr. Ent. & Keltern & ISSN 0005-805X \\
\hline $\mathbf{5 6}(2006) 2$ & S. $451-462$ & 15.12 .2006 \\
\hline
\end{tabular}

\title{
Industrial emissions and pesticides impact on agrobiocenosis biodiversity
}

With 2 figures

\author{
Iuliana Antonie and Irina Teodorescu
}

\begin{abstract}
Summary
This contribution presents the results of a long-term study (1987-2004) on the influence of industrial emissions and pesticides on the surface-dwelling arthropod populations of agricultural fields with crops of cereals, potato, sunflower, cabbage and sugarbeet. Particular attention was given to the insects. The agricultural areas exposed to pollutants were compared with control areas not exposed to the chosen influencing factors. The structure of communities of arthropods in biocenoses affected by pesticides and industrial emissions was strongly affected by the toxic pollutants. The influence on the biodiversity of agro-ecosystems is reflected in the quantative and qualitative structure of the collected samples, by a reduction in the number of species and individuals, differences in the species composition and in the composition of trophic groups as well as by differences in population dynamics. Not only was the number of species and individuals of arthropods on plots exposed to industrial emissions and pesticides consistently reduced, but also the number of higher taxonomic categories (classes, orders, families, genera). Predators were numerically dominant on the control areas, phytophages in the affected plots. The quantative relationship between primary and secondary consumers is a good indicator for the estimation of agro-biodiversity. Aranea and Coleoptera showed a certain resistance to the negative effects of toxic substances, which could be shown by their abundance and frequency of appearance. The structural and functional alterations to arthropod communities as a result of exposure to industrial emissions and pesticides are equally applicable to other taxonomic and trophic categories. They are therefore suitable as indicators for the reduction in biodiversity at the level of complete biocenoses. Reductions in biodiversity have in turn an influence on the productivity and the stability of a biocenosis in both space and time.
\end{abstract}

\section{Zusammenfassung}

In diesem Beitrag präsentieren wir die Ergebnisse eine Langzeitstudie (1987-2004) über den Einfluss von Industrieemissionen und Pestiziden auf die oberirdischen Arthropodenpopulationen landwirtschaftlicher Nutzflächen mit Getreide-, Kartoffel-, Sonnenblumen-, Kohl- und Zuckerrübenkulturen, wobei insbesondere Insekten untersucht wurden. Den Schadstoffen ausgesetzte Agrarflächen wurden mit Kontrollflächen ähnlicher Kulturen, die den ausgewählten Einflussfaktoren nicht ausgesetzt waren, verglichen. Die Gemeinschaftsstruktur der Arthropoden von Biozönosen, die Pestiziden und Industrieemissionen ausgesetzt waren, wurden durch die genannten toxischen Schadstoffe stark beeinflusst. Der Einfluss auf die Biodiversität von Agro-Ökosystemen spiegelt sich in der quantitativen und qualitativen Struktur der gesammelten Stichproben durch verringerte Anzahl von Arten und Individuen, Unterschiede in der Artenzusammensetzung und in der Zusammensetzung der trophischen Gruppen sowie in der Populationsdynamik wider. Sowohl die Anzahl höherer taxonomischer Kategorien (Klassen, Ordnungen, Familien, Gattungen), als auch die Anzahl von Arten und Individuen von Arthropoden war auf Stichprobenflächen, die industriellen Emissionen und Pestiziden ausgesetzt waren, stets geringer. Prädatoren waren auf den Kontrollflächen zahlenmäßig dominant, phytophage Arten in den exponierten Kulturen. Das quantitative Verhältnis zwischen Primär- 
und Sekundärkonsumenten ist ein guter Indikator für die Abschätzung der Agro-Biodiversität. Aranea und Coleoptera zeigten eine gewisse Resistenz gegenüber den negativen Auswirkungen von toxischen Substanzen, was anhand der Abundanz und Frequenz ihres Auftretens nachgewiesen werden konnte. Die strukturellen und funktionalen Veränderungen von Arthropoden auf der Ebene von Gemeinschaften infolge der Exposition gegenüber Industrieemissionen und Pestiziden sind auch auf andere taxonomische und trophische Kategorien übertragbar. Sie sind daher als Indikatoren für die Minderung der Diversität auf der Ebene der gesamten Biozönosen geeignet. Verminderungen der Biodiversität auf biozönotischer Ebene haben wiederum Auswirkungen auf die Produktivität und die Stabilität von Biozönosen in räumlicher und zeitlicher Hinsicht.

\section{Key words}

industrial emissions and pesticides impact, agricultural landscapes biodiversity

\section{Introduction}

Human activities cause physical-chemical and biological disturbances in the environment (air, water, soil), which can be either manifest immediately, or be quantifiable only after long periods (storing effect) (Pizzolotto 1994). Toxic effects are targeting not only human, but all other organisms, which can be affected at different levels of programs: inferior programs (by molecular, cell, tissue, toxicity), programs for self (by acute and chronic intoxication, cancerigen effects leading to death) and superior programs (mutagenic and teratogenic effects affecting the descendents number, quality and viability) (Teodorescu et al. 2001).

The effects of diverse chemical substances resulted from human activity on populations and biocoenosis, and the tolerance limits of all species and ecological systems, are not well known, so in-depth research is needed to asses the impact rate and to assure the fundament of an efficient surveillance of the environment quality (Teodorescu et al. 1985; Teodorescu 1985).

In this paper we present the results of 17 years research aiming to assess the impact of the industrial emissions and pesticides on the aboveground arthropods populations, focusing on insects, by comparison to "control" (similar crops), unexposed to the respective pollutant factors.

\section{Material and methods}

This study was performed during 1987 and 2004, using as sampling method, pitfall traps (plastic or glass containers of $100 \mathrm{~mm}$ in diameter, $500 \mathrm{ml}$ in volume), placed at soil level ( 5 traps/crop, at $10 \mathrm{~m}$ distance from each other, 4 in the corners and one in the centre). Sampling areas were located especially in Romanian south regions, but in some cases, in other parts of the country. Trapped individuals were collected weekly on the entire period of the research. Were investigated corn, potato, sunflower, brassicaceae, and sugar beet, crops.

Pitfall traps are the most known and the most often used inventory method in agro ecosystems (Duelli 1997; Duelli et al. 1999). They are commonly used to address a question of difference in population size or community structure in time or space (Melbourne 1999). 
The advantages of this method are represented by continuous collection, during the entire period of research, on a large surface, the collection of night activity arthropods, the capture of arthropods living mainly on the aboveground level and belonging to all consumer categories (primary, secondary, tertiary, quaternary, coprophagous, necrophagous, detritophagous, omnivorous). This method has also some limits: it can provide only partial qualitative information (assuring only accidentally collection of the well-flying species or those feeding with the air organs of plants, but not endophyte or hypogeal ones) and assure only half-quantitative estimations, because the reference to the surface unit is not possible.

Some crops were placed in the vicinity of industrial platforms (200-800 m) and exposed to industrial emissions (mainly represented by $\mathrm{SO}_{2}, \mathrm{CO}_{2}, \mathrm{CO}, \mathrm{Pb}$, fluor, chloride, hydrochloric acid, vinyl, ethylene, propylene, aniline, phenol, formaldehyde, aliphatic carbonates etc).

We also studied chemically polluted crops treated with insecticides Fosalon - 0,7 kg/ha, against Leptinotarsa decemlineata; or herbicides Icedin-Super CS (2,4 D as DMA salts $29 \%$ + Dicamba $10 \%$ ), 1 l/ ha, 2,4-d-Isopropylamine Salt LS-2,4 D (isopropyl amine salts 2,4-d acid a.e. 33 \%), 2,5 l/ha, Sansulfuron 75 WP (chloridesulfon 75\%), 15-20 g/ha, Granstar 75 DF (tribenuron methyl $75 \%$ ) and Asulox 40 SL CS (asulam $400 \mathrm{~g} / \mathrm{l}$ ).

The "control crops" were represented by crops placed farther from the industrial emission sources (10-50 km), by similar crops without pesticides intervention, or the same crop, before the pesticides treatment.

The influence of previous or adjacent crop and of the variations of non-biotic factors (temperature, raining, strong wind), on the structure and dynamics of the aboveground arthropods populations was also investigated. For this purpose, three trapping stations have been set in some crops, at the borderline area with other different crops.

The pitfall traps material was preserved in ethanol and submitted to qualitative and quantitative analyses.

Qualitative analysis: material determination, to the species level in most of the cases; framing species in trophic categories; establishing both the specific pests, the adjacent and previous crop pests, the phytophagous polyphagous species; establishing the beneficial species (predators, parasitoids, pollinator, coprophagous, necrophagous, detritophagous).

Quantitative analysis: comparison between species and specimens number in control and polluted crops; assessment species and specimens numerical abundance and frequency; assessment species richness; establishing the dominant and constant species, orders and classes, based on numerical abundance and frequency values; comparison of the trophic categories biomass.

\section{Results and discussions}

We have selected the aboveground arthropods for the biodiversity investigation, because these small organisms (particularly the insects), easily collected in pitfall traps, are the main group from the total known species.

Research objectives were: to demonstrate the difference between the epigeal arthropods fauna structure in "control" and affected by pesticides and industrial emissions crops, 
and to underline the adjacent and previous crops and non-biotic factors influence on the biological diversity, in order to characterise the status of agricultural biodiversity, by assessment of some qualitative and quantitative parameters.

In agrobiocoenosis are integrate various categories of organisms as primary producers, different degrees of consumers and decomposers. The organisms belonging to these trophic categories are of great variety: Bacteriophyta, Mycophyta, Protozoa, Vermes, Mollusca, Annelida, Arthropoda (Arachnida, Crustacea, Diplopoda, Chilopoda, Insecta), Amphibia, Reptilia, Aves and Mammalia. A research program, extended on all trophic categories belonging to different higher taxa of organisms, should require a great number of researchers and a long period of time for the data processing.

In this study we have investigated only the consumer categories of Phylum Arthropoda, because we considered that the changes occurred in arthropods populations, under the influence of pesticides or industrial noxious toxicity, could be extrapolated allowing the estimation of human activities impact at biocoenosis level (Teodorescu 1989, 1994, 1998, Teodorescu et al. 1997, 1999, 2001).

\section{Comparison of arthropod fauna structure in control and polluted crops}

Were detected some similar features in the polluted and control crops: the presence of arthropods species belonging to Crustacea, Myriapoda, Arachnida and Insecta classes; high prevalence of insects species and specimen numbers; the dominance of aboveground arthropod species; the existence of the same trophic categories of consumers (Fig. 2).

From Crustacea class, in some samples occurred few specimens of Armadilidium vulgare Latr., from Armadilidiidae family, Isopoda order.

From Diplopoda there were collected species belonging to Julidae (Julus territories L., Blaniulus gutulatus Bosc.) and Polydesmidae (Polydesmus complanatus L.) families, and from Chilopoda, species belonging to Lithobiidae (Lithobius forficatus L.) and Geophilidae (Geophilus sp.) families.

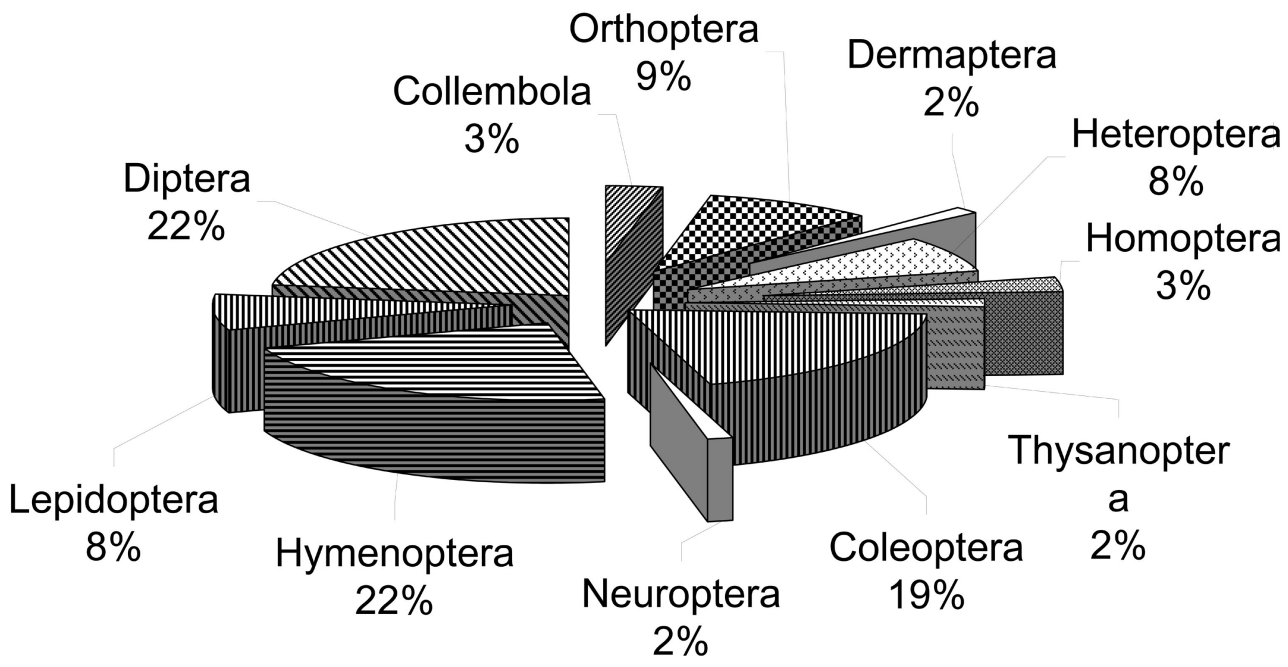

Fig. 1: Insect families' distribution function of orders. 


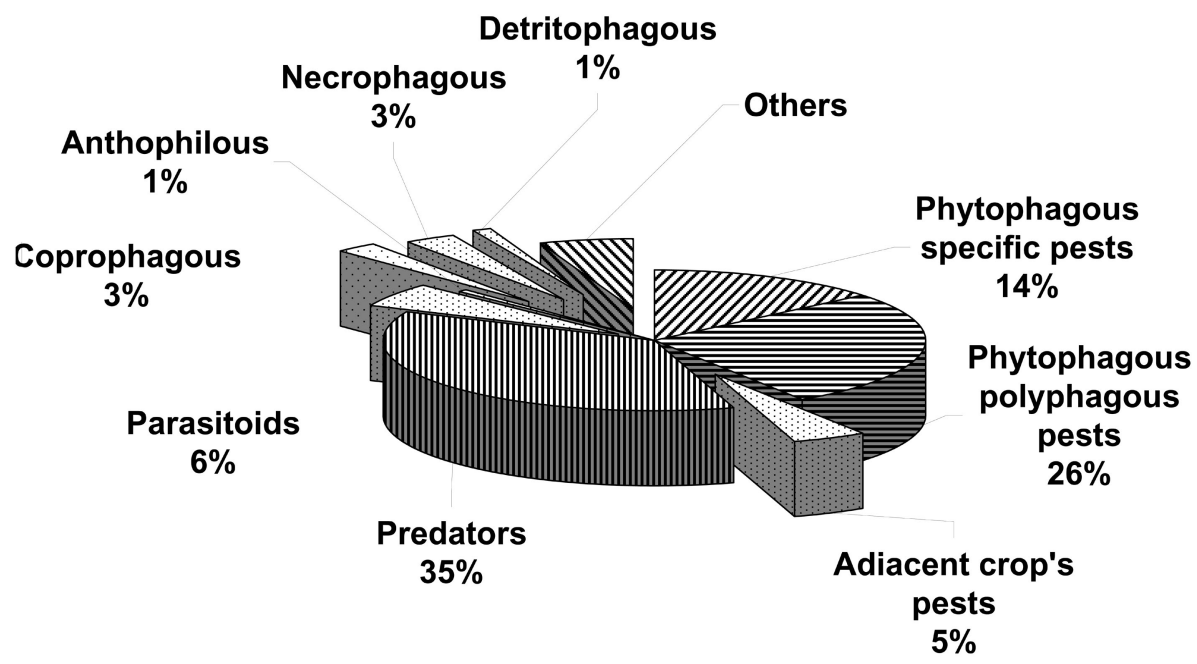

Fig. 2: Insect species trophic categories distribution.

Arachnida class was represented by the Acarina and Aranea groups, but genera and species remain undetermined.

Insecta class was represented by over 200 species, belonging to 66 families and 11 orders (Fig. 1): Collembola (Sminthuridae, Entomobryidae), Orthoptera (Gryllidae, Gryllotalpidae, Catantopidae, Tettigoniidae, Acrididae, Decticidae), Dermaptera (Forficulidae), Heteroptera (Anthocoridae, Nabidae, Miridae, Reduviidae, Pentatomidae), Homoptera (Aphididae, Cicadellidae), Thysanoptera (Thripidae), Coleoptera (Carabidae, Harpalidae, Malachiidae, Staphylinidae, Silphidae, Elateridae, Tenebrionidae, Dermestidae, Cantharidae, Coccinellidae, Scarabaeidae, Chrysomelidae, Curculionidae), Neuroptera (Chrysopidae), Hymenoptera (Tenthredinidae, Braconidae, Aphidiidae, Megaspilidae, Serphidae, Diapriidae, Scelionidae, Encyrtidae, Pteromalidae, Trichogrammatidae, Dryinidae, Vespidae, Myrmicidae, Formicidae, Apidae), Lepidoptera (Gelechiidae, Pyralidae, Plutellidae, Noctuidae, Pieridae) and Diptera (Culicidae, Mycetophilidae, Itonididae, Asilidae, Stratiomyiidae, Empididae, Dolichopodidae, Chamaemyiidae, Syrphidae, Drosophilidae, Calliphoridae, Muscidae, Chloropidae, Sarcophagidae, Tachinidae).

Total number of Arthropoda species it is not known, because all Aranea, Acarina, Braconidae, Encyrtidae, Myrmicidae, Tachinidae and some Collembola, Pteromalidae, Formicidae, remained indeterminate.

The characteristic species, residing on the aboveground and low plants, were represented by the orders Collembola, Coleoptera (Carabidae, Harpalidae, Staphylinidae families, some Curculionidae from genera Tanymecus, Bothynoderes), Orthoptera (Gryllidae, Gryllotalpidae, Catantopidae, Decticidae, Tettigoniidae, Acrididae families), Hymenoptera (Formicidae and Myrmicidae families), Aranea, Diplopoda (Iulidae and Polydesmidae families), Chilopoda (Lithobiidae and Geophilidae families).

Not characteristic for the aboveground fauna, many phytophagous, predators, pollinators, parasitoids, coprophagous and necrophagous species belonging to Heteroptera, Homoptera, Thysanoptera, Neuroptera, Hymenoptera, Coleoptera, Lepidoptea, Diptera orders, were frequently collected in the traps. The presence of Culicidae, Itonididae, 
Drosophilidae, Calliphoridae, Sarcophagidae, Chloropidae and Muscidae etc. species, was accidental.

Diversity of phytophagous insects was generally high: Gryllidae, Gryllotalpidae, Catantopidae, Decticidae, Acrididae, Tettigoniidae (Orthoptera), Cicadellidae, Aphididae (Homoptera), Pentatomidae (Heteroptera), Thripidae (Thysanoptera), Harpalidae, Carabidae, Elateridae, Tenebrionidae, Scarabaeidae, Chrysomelidae, Curculionidae (Coleoptera), Tenthredinidae (Hymenoptera), Noctuidae (Lepidoptera), Itonididae, Chloropidae (Diptera). Some Orthoptera, Coleoptera are omnivorous, but predominantly phytophagous.

From the human point of view, some species have been considered pests, others beneficial.

Pests were represented by phytophagous, specific to respective crop, specific pests to adjacent or previous crops, polyphagous species, accidental species coming from other crops and wild plants.

Beneficial species were represented by predator, parasitoid, pollinator, coprophagous, necrophagous, detritophagous arthropods.

\section{- Diversity of specific crop pests:}

For potato crops, the number of arthropods species was also reduced because of the plant solanin, accessible only for a small number of phytophagous: Macrosiphum euphorbiae Hott et Fris, Aulacorthum solani Kalt. (Aphididae), Empoasca solani Curt. (Cicadellidae), Leptinotarsa decemlineata Say (Chrysomelidae), Phthorimaea operculella Zell. (Gelechiidae), thus constitute only a poor trophic network.

In the corn crops, specific pest have accidentally occurred: Rhopalosiphum maydis Fitch. (Aphididae), Ostrinia nubilalis Hb. (Noctuidae), Pentodon idiota Hbst. (Scarabaeidae), but registered a marked prevalence of Tanymecus dilaticollis Gyll. (Curculionidae), Agriotes obscurus L., A. ustulatus Schall. (Elateridae), Pedinus femoralis F. (Tenebrionidae).

In the cabbage, cauliflower crops occurred: Brevicoryne brassicae L. (Aphididae), Eurydema ornatum L., E. oleracea L. (Pentatomidae), Phyllotreta atra F., Ph. nemorum L., Ph. undulata Kut. (Chrysomelidae), Ceuthorrhynchus assimilis Payk., C. quadridens Panz. (Curculionidae), Plutella maculipennis Curt. (Plutellidae), Mamestra brassicae L. (Noctuidae), Pieris brassicae L. (Pieridae), Hylemyia brassicae Bché. (Muscidae).

In the sugar beet crops, Bothynoderes punctiventris Germ., Tanymecus palliatus F. (Curculionidae), Aphis fabae Scop. (Aphididae) species were frequently encountered, and. Blitophaga opaca L, Blitophaga (Aclypea) undata Müll. (Silphidae), Cassida nebulosa L., Chaetocnema tibialis Illig. (Chrysomelidae), Gnorimoschema ocellatella Boyd. (Gelechiidae) species were accidentally.

In the sunflower crops, the specific pest was Homoeosoma nebulella Hb. (Lepidoptera Pyralidae).

- Diversity of polyphagous or adjacent crop pests, of other species trophic correlated with spontaneous plants was high.

These species belonging to Orthoptera from families Tettigoniidae (Tettigonia viridissima L., T. caudata Ch.), Decticidae (Decticus verrucivorus L.), Gryllidae (Gryllus campestris L., Gryllulus desertus Pallas, G. frontalis Fieb.), Gryllotalpidae (Gryllotalpa gryllotalpa Latr.), Catantopidae (Calliptamus italicus L.) and Acrididae (Acrida hungarica Hbst., 
Dociostaurus maroccanus Thunb., Oedipoda coerulescens L.), Homoptera from families Aphididae (Aphis fabae Scop., Schizaphis graminum Rond., Sitobion avenae Fabr.) and Cicadellidae (Euscelis plebejus Fall., Macrosteles laevis Ribaut.), Heteroptera from families Miridae (Lygus rugulipennis L., Lygus pratensis L.) and Pentatomidae (Dolycoris baccarum L.), Thysanoptera-Thripidae (Thrips tabaci Lind.), Coleoptera from families Harpalidae (Harpalus rufipes Deg., H. azureus F., H. aeneus F., H. griseus Panz., H. distinguendus Duft, H. tardus Panz.), Carabidae (Anisodactylus signatus Panz., A. binotatus F., Amara aenea Deg., A. similata Gyll., A. ovata F., A. eurynota Panz., A. familiaris Duft., Zabrus tenebrioides Goeze), Elateridae (Agriotes lineatus L., A. ustulatus Schall., A. obscurus L., A. sputator L., Athous niger L., Selatostomus latus L., S. aeneus L., Melanotus punctolineatus Pell.), Tenebrionidae (Opatrum sabulosum L., Gonocephalum pussilum Fabr., Blaps letifera Marsh.), Chrysomelidae (Entomoscelis adonidis L., Longitarsus anchusae Payk., L. pellucidus Foudr., L.. tabidus Fabr., Aphthona euphorbiae Schrank., Gastroidea polygoni L., Lema melanopus L.) and Curculionidae (Psalidium maxilosum F., Sitona lineatus L.), Hymenoptera-Tenthredinidae (Athalia spinarum F.), Lepidoptera Noctuidae (Scotia segetum Den. et Schiff., S. ypsilon Rott., S. exclamationis L., Autographa gamma L., Margaritia sticticalis L.), Diptera from families Itonididae (Mayetiola destructor Say), Chloropidae (Chlorops pumilions Bjerk., Oscinis frit L.).

- Diversity of predator species and higher taxa was high, represented less by Chilopoda and more by Aranea and Insecta:

Heteroptera from families: Nabidae (Nabis ferus L., N. rugosus L.), Miridae (Orius niger Wolff.), Adelphocoris lineolatus Goeze.), Reduviidae (Reduviuspersonatus L.), Anthocoridae (Anthocoris nemorum L., A. nemoralis F.), Coleoptera from families Carabidae (Carabus coriaceus L., C. scabriusculus, C. cancellatus Illig., C. ulrichii Germ. C. intricatus L., Calosoma maderaeauropunctatum Hbst., Pterostichus koyi marginalis Dej., P. lepidus Leske., P. niger Schall., P. nigrita F., P. vulgaris L., P. madidus Fabr., P. melas Creutz., Poecilus cupreus L., Abax ater Villa, A. carinatus Duft., A. paralellus Duft., A. parallelopipedus Dej., Dolichus halensis Schall., Idiochroma dorsalis Pont., Dyschirius strumosus L., Brachynus crepitans L., B. explodens Duft., B. psophia Serv., Bembidion properans Steph., B. varium Oliv., Lebia crux minor L., L., cyanocephala L., L. humeralis Dej., L. marginata Geoggr., Microlestes maurus Sturm.), Malachiidae (Malachius bipustulatus L., M. rubidus Er.), Staphylinidae (Aleochara lanuginosa Grav., Tachyporus hypnorum F., Creophilus maxilosus L., Staphylinus caesareus Cederh, S. olens Müll etc.), Cantharidae (Cantharis annularis Mén., C fusca L., C. rufa L., rustica Fall.) and Coccinellidae (Coccinella septempunctata L., Adalia bipunctata L., Coccinula quatuordecimpustulata L., Adonia variegata Goeze.); Neuroptera-Chrysopidae (Chrysopa carnea Steph., C. septempunctata Wesm., Nineta flava Scop.); Hymenoptera from families Vespidae (Vespa crabro L, Dolichovespula rufa L., D. vulgaris L.), Formicidae (Formica rufa L.), Diptera from families Syrphidae (Syrphus ribesii L., Episyrphus balteatus Deg., Sphaerophoria scripta L.), Chamaemyiidae (Leucopis. ninae Tanas., L. atritarsis Tanas., L. caucasica Tanas., L. glyphinivora Tanas., L. melanopus Tanas.), Dolichopodidae (Dolichopus sp.), Asilidae (Asilus sp., Laphria sp.) and Empididae.

- Diversity of parasitoid species and higher taxa was low, belonging especially to Hymenoptera from families Braconidae, Aphidiidae (Diaeretiella rapae Curt., Lysiphlebus fabarum Marsh.), Serphidae (Serphus gravidator L.), Diapriidae (Trichopria cilipes Kieff., Diapria conica L.), Scelionidae (Teleas rugosus Kieff. ), Dryinidae (Gonatopus sepsoides 
Westw.), Pteromalidae (Pteromalus puparum L., Encyrtidae, Trichogrammatidae and Diptera Tachinidae.

From parasitoids, Hymenoptera were specific for the pest key species: Diaeretiella rapae Curt., for Brevicoryne brassicae L.; Teleas rugosus Kieff., for Zabrus tenebrioides Goeze; Pteromalus puparum L., for Pieridae, Gonatopus sepsoides Westw., for Cicadellidae.

Some parasitoids were hosted by polyphagous pest: Lysiphlebus fabarum Marsh., on Aphis fabae Scop.; Serphus gravidator L. on Harpalus, Amara species; Trichogramma evanescens Westw., on Noctuidae, Tortricidae species etc.

In the samples from control crops, predators (aranea and insects) were numerous as species and specimens, represented by Nabidae, Myridae, Anthocoridae, Reduviidae (Heteroptera), Carabidae, Staphylinidae, Coccinellidae, Cantharidae (Coleoptera), Syrphidae (Diptera). The parasitoids were less numerous. The zoophagous were numerically dominant in comparison with the phytophagous species.

In the samples from polluted crops, the predators were represented mainly by Aranea, Carabidae, Staphylinidae, and the parasitoids were less numerous or even absent.

- Diversity of pollinator, necrophagous, coprophagous, detritophagous species and higher taxa was low, both in control and polluted crops.

Pollinator species belonging especially to Apoidea, occurred only accidentally.

Necrophagous species, belonging to Silphidae (Necrophorus antennatus Reitt., N. germanicus L., N. vespillo L.) and Dermestidae (Dermestes lardarius L., D. laniarius Illig., D. murinus L.), occurred only accidentally.

Coprophagous species, belonging to Scarabaeidae (Geotrupes stercorosus Scriba, Onthophagus taurus Scriba, Pleurophorus caesus Panz., Platysoma lineare Er., Caccobius sp.), were also collected in the samples.

Detritophagous species, represented especially by Collembola, were sporadically captured in both crop categories.

- Other insects, without any trophic connection to the respective crops, were:

Culicidae (Culex sp., Aedes sp.), Mycetophylidae, Itonididae, Stratiomyiidae (Stratiomyia sp.), Drosophilidae (Drosophila sp.), Calliphoridae (Calliphora erythrocephala Mg., C. vomitoria L., Lucilia caesar L., Phaenicia sericata Mg.), Sarcophagidae (Sarcophaga carnaria L.) and Muscidae (Stomoxys calcitrans L.).

It is to be mentioned the strong relationship between the biodiversity level, on one side and the type, state of crop and the variation of the non-biotic factor values, on the other side. Usually, the number of arthropods species, and particularly of specimens, decreased in time, this correlating with the animals and plants biological cycle and the decrease of the food quality. In the two years investigated crops, the fauna structure was greatly influenced by the significant variations of temperature and moisture.

Comparison between the species and specimens number in samples collected from control crops, industrial emissions affected and chemically treated crops

The analysis of the aboveground arthropods evidenced some differences of the diversity, in the samples collected from control, and pesticides or industrial emissions exposed crops. 
The species number was expressed by approximate values, because in some cases, the species determination could not be achieved. In the samples from pesticides treated crop, the number of species was $2-3$ or even more than 4 times smaller than in the samples from control crop.

The specimen's number was also bigger in the samples from control crop, but depending on the type of the investigated crop. This number was influenced by the adjacent crops structure, by the time of samples collection and by the values of the non-biotic factors in a certain period of time.

\section{Comparison of the abundance and the dominance values in the samples from control and polluted crops}

The biggest differences in the total number of specimens in the samples from control and industrial emissions polluted crop were noticed in maize crop (about 9 times), near some industrial platforms.

In the samples from control crops, the highest values of the numeric abundance were reached in most of the cases by Coleoptera (60-90 \%), less by Hymenoptera (mainly aboveground species). Through their size, the Coleoptera, especially Carabidae (Carabus, Calosoma, Poecilus, Abax, Pterostichus, Brachinus) and Staphylinidae, were dominant in the biomass. Smaller values of the numeric abundance in samples from control crops were registered for the coprophagous, necrophagous, detritophagous, parasitoids (in the last case, partially due to the selective feature of the collection method).

In the samples from polluted crops, the Coleoptera were dominant by phytophagous species of Harpalus, Amara, Opatrum, Agriotes and Leptinotarsa. In most of the cases, an increasing in spider's number was registered. In the biomass, the phytophagous Coleoptera and Orthoptera (Gryllidae, Gryllotalpidae, Tettigoniidae, Catantopidae, Decticidae, Acrididae) were dominant. Smaller values of the numeric abundance in the samples from polluted crops were registered especially for parasitoids, coprophagous, necrophagous, detritophagous species.

\section{Comparison of the number of species and specimens from different trophic categories}

In the samples from control crops, a clear domination of the secondary consumers (especially predators) was noticed, as comparing to the primary ones (phytophagous), 2-3 times bigger as number of species, but especially as number of specimens (3-4 times bigger). This fact has a strong positive relevance, because these secondary consumers are biotic control factors, pest species being maintained at low levels densities.

In the samples from polluted crops, the primary consumers dominated as species and specimens number, because lack or diminish biological control (from predators and parasitoids), and also because of their capacity, as phytophagous, to resist of the pollutant toxicity effects.

The changes in the dominance pattern of primary-secondary consumers represent a good indicator of the biological diversity reduction and consequently, of the ecological imbalance induced by noxious factors with anthropic origin (Popa and Teodorescu 1983).

The pollinator species were noticed especially in control samples, but their low number could be the consequence of the collection method, which excludes, at least partially, the anthophylous species. 
The presence of coprophagous, necrophagous, detritophagous species was accidental in the samples from polluted and control crops, having a small number of specimens.

\section{Insect dominance in the aboveground arthropods community structure}

Taxonomically, the insects were dominant in all the cases, sometimes with a frequency of $100 \%$. The Arachnida class exhibited a high frequency, especially in the polluted crops, but sometimes in controls, too.

As the number of Aranea increased in polluted crops, we consider that some of them resist to the industrial noxious and pesticides toxic action.

In the samples from control crops, the most frequently encountered species (euconstant) were the insects belonging to the orders Coleoptera, Hymenoptera (through aboveground level species) and Diptera (more often Drosophilidae). Constantly encountered were Orthoptera, Aranea, and accidentally, Isopoda, Chilopoda, Diplopoda, Collembola, Neuroptera, Dermaptera, Lepidoptera species.

In the samples from polluted crops, euconstant were Aranea and Coleoptera and constant, Orthoptera, Homoptera, Heteroptera, Hymenoptera and Diptera species.

\section{The dynamics of the species composition and specimen's number, in the samples from control and polluted crops}

Species composition changes considerably in most habitats during a season (Duelli et al. 1999).

In the samples from control crops, the factors, which explain the species composition and the specimen dynamics, were represented by accomplishment of their own biological cycle, the character of the crops, the immigration from the adjacent habitats, the variation of non-biotic factors.

In the samples from polluted crops, the factors responsible for the species composition and specimen dynamics were both natural (as in the control crops) and anthropic (pesticides and industrial emissions).

In the crops exposed to pesticides, the dynamics was very different. In some cases, in the first days following the chemical treatment, the number of species and specimens were drastically reduced due to the pesticides shock effect. In other cases, this number significantly decreased to the end of the investigated period, when the toxic action reached its summit, and as a result of accumulation and concentration pesticides along the trophic chains. In localized chemical treatments, there has been a gradual fauna components reinstallation, reflected in the arthropods species number, but especially of specimens reincreasing, through the immigration from areas where the crop has not been treated, from spontaneous plants or near by zones unaffected by pesticides.

All these data are warning on the negative effects of the human intervention in the structure, and implicitly, in the functioning of agricultural biocoenosis.

\section{Conclusions}

The arthropod community's structure from the biocoenosis exposed to pesticides and industrial emissions was strongly influenced by these toxic substances. From the individual level, the negative effects could be extended to the population and biocoenotic level. The biodiversity was in all cases much bigger in the samples from control crops. 
The number of arthropods higher taxa (classes, orders, families, genera) has always been smaller in the samples from pesticides and industrial emissions exposed crops.

The number of species and specimens in samples from control crops was bigger that in samples from the chemically treated crops or the ones collected near by the industrial noxious sources.

The predator species were numerically dominant in the samples from unpolluted crops, and the phytophagous species in the samples from polluted crops.

The quantitative proportion between primary and secondary consumers, favouring the first in polluted crops, and the last ones in the control crops, is a good indicator of the biodiversity assessment.

A certain resistance to the negative action of the toxic substances was registered for Aranea and Coleoptera, and revealed by the numerical abundance and frequency values.

Some categories considered beneficial (parasitoids, pollinators, coprophagous necrophagous and detritophagous species) were generally represented by a low number of species and specimens, partially due to the use of a method specific to the collection of the aboveground fauna.

It must be underlined the importance of the adjacent habitats or landscapes in determining the species richness.

The functional modifications at the arthropods community level, consequently to the structural modifications are related to the alteration of the consumers role of matter, energy and information transporters.

In the control crops with a greater number of species and specimens, exist a higher biodiversity, and in consequences, a higher stability at the biocoenotic level.

In the pesticides and industrial emissions affected crops, the instability increasing, as a result of biodiversity diminution.

\section{References}

Duelli, P. 1997: Biodiversity evaluation in agriculture landscapes: An approach at two different scales. - Agriculture, Ecosystems and Environment, Elsevier Science 62: 81-91.

Duelli, P.; Овrist, K. M. \& Schmatz, R. D. 1999: Biodiversity evaluation in agriculture landscapes. - Agriculture, Ecosystems and Environment, Elsevier Science 74: 33-64.

Melbourne A. B. 1999: Bias in the effect of habitat structure on pitfall traps: An experimental evaluation. - Australian Journal of Ecology 24: 228-239.

Pizzolotтo, R. 1994: Soil arthropods for faunal indices in assessing changes in natural value resulting from human disturbances. - In: Biodiversity, Temperate Ecosystems, and Global Changes. Edited by Boyle, T. J. B., Boyle, C. E. - NATO ASI Series, vol. 120, Springer-Verlag Berlin, Chapter 15: 291-313.

Popa, I. \& Teodorescu, I. 1983:, Evoluția populațiilor ploşnitelor cerealelor în județul Dolj, în condițiile sistării tratamentelor chimice, pentru favorizarea paraziților oofagi. - Lucrările celei de a VIII-a Conferințe Naționale de Protecția Plantelor: 273-281.

Teodorescu, I.; Popa, I. \& Petrescu, I. 1983: Contribuția scelionidelor oofage (Proctotrupoidea, Scelionidae) la protecția culturilor de grau din județul Dolj, față de atacul produs de speciile de Eurygaster (Heteroptera). - Lucrările celei de a III-a Conferințe Naționale de Entomologie: 627-634.

TeOdorescu, I. 1985: Unele implicatii ecologice ale utilizarii pesticidelor în ecosistemele terestre. - Buletinul de ecologie 2: 62-74. 
Teodorescu, I. 1989: Contributions a la connaissance des effets de la pollution industrielle sur certaines biocoenosis des agrosystemes adjacents aux sources d' emission. - Analele Universitatii Bucuresti, Anul XXXVIII: 71-79.

TeOdorescu, I. 1994: The industrial pollution effects upon some agrobiocenosis from the adjacent agro systems around the emission sources. - Ocrotirea naturii şi a mediului înconjurător, tom 38, 1: 27-44.

Teodorescu, I. 1998: Acțiunea ierbicidelor asupra populațiilor de artropode din culturi. - Studii si Cercetari de Biologie Seria Biologie Animala, tom 50, 1: 11-36.

Teodorescu, I. \& Vădineanu, A. 1997: The pesticide pollution impact on the structure and dynamics of the arthropod associations. - Revue Roumaine de Biologie. Serie de biologie animale, Bucarest, tome 42, 1: $125-135$.

Teodorescu, I. \& Vădineanu, A. 1997: Negative action of industrial emission upon ground level arthropod populations. - Revue Roumaine de Biologie. Serie de biologie animale, Bucarest, tome 42, 2: 237-248.

Teodorescu, I. \& Vădineanu, A. 1999: Industrial emissions and pesticides impact upon insect populations. - Internationale Entomologen-Tagung, Basel: pp. 116.

Teodorescu, I. \& Vădineanu, A. 1999: Controlul populaţiilor de insecte. - Editura Universităţii din Bucureşti. - ISBN 973-575-368-5.

Teodorescu, I. \& Vădineanu, A. 2001: Managementul capitalului natural, studii de caz. - Editura Ars Docendi, Bucureşti. - ISBN 973-8118-59-X.

Subject editor: H. H. DATHE

\section{Author's address:}

Dr. Iuliana Antonie

Faculty of Agricultural Sciences

Alimentary Industry and Environment Protection

Str. Oituz Nr. 31, RO - 2400 Sibiu, Romania

e-mail: iuliana_antonie@yahoo.com
Prof. Dr. Irina Teodorescu

University of Bucharest, Faculty of Biology

Spl. Independentei 91-95

$\mathrm{RO}$ - 050095 Bucharest, Romania

e-mail: iteodorescu@bio.unibuc.ro 